PUSTABIBLIA: Journal of Library and Information Science

ISSN 2549-3493 (Print); ISSN 2549-3868 (Online)

DOI: http://dx.doi.org/10.18326/pustabiblia.v3i2.141-157

SK Dirjen Risbang-Kemristekdikti No 23/E/KPT/2019 (Peringkat 4 SINTA)

\title{
Mengenal E-Book di Perpustakaan
}

\author{
Fahrizandi \\ Pustakawan pada IAIN Pontianak \\ Email: fahrizandii@gmail.com
}

\begin{abstract}
The title of this article is to know e-books in the library, this paper aims to explain what are the types, advantages and disadvantages of e-books, then how to improve performance strategies in developing e-book collections. The results of the analysis of the literature, the library must develop a collection of e-books to meet the expectations of users of information. The types of e-books can be distinguished from the nature of access, form, and mode of production. The advantages of e-books are 1) fast traceability; 2) more frequent modifications; 3) portability; 4) variations; 5) legibility; 6) value added features; 7) space savings. The weaknesses of the e-book are 1) reading on the screen; 2) battery power; 3) security problems 4) permanent 5) lack of standardization; 6) borrow books; 7) hidden costs; and 8) direct costs. Meanwhile, the main strategy is to improve the performance of librarians through efforts job redesign, delegation, skill trainin, and career development.
\end{abstract}

\section{Abstrak}

Judul artikel ini adalah mengenal e-book di perpustakaan, tulisan ini bertujuan untuk menjelaskan apa saja jenis-jenis, keuntungan serta kekurangan e-book, selanjutnya bagaimana strategi meningkatkan kinerja dalam mengembangkan koleksi e-book . Hasil analisis dari literatur, maka perpustakaan harus mengembangkan koleksi e-book untuk memenuhi harapan pemustaka terhadap informasi. Jenis-jenis e-book dapat dibedakan dari sifat akses, bentuk, dan cara produksi. Keuntungan e-book adalah 1) keterlelusuran cepat; 2) modifikasi lebih sering; 3) portabilitas;4) variasi; 5) keterbacaan; 6) fitur nilai tambah; 7) penghematan ruang. Sisi kelemahan 
e-book adalah 1) membaca di layar; 2) daya baterai; 3) masalah keamanan 4) permanen 5) kurangnya standarisasi; 6) meminjam buku; 7) biaya tersembunyi; dan 8) biaya langsung. Sedangkan, strategi utama utntuk meningkatkan kinerja pustakawan melalui upaya job redesign, delegation, skill training dan career development.

Kata kunci: e-book, library, performance of librarians

\section{Pendahuluan}

Berabad-abad yang lalu, perpustakan identik dengan tempat penyimpanan dan penyebaran informasi berupa media tercetak, disusun sesuai dengan aturan tertentu, koleksi nampak sedikit berdebu jika lama tidak gunakan dan dibersihkan, bahkan sedikit terkesan "angker" saat membuka buku di antara tumpukan buku-buku langka. Di sisi pemustaka, tidak semua orang mau memanfaatkan perpustakaan secara maksimal dengan berbagai alasan, mulai dari lokasi perpustakaan yang jauh dari tempat tinggal, waktu buka terbatas, dan tidak tidak ada rasa ini tahu dari masyarakat. Di sisi pustakawan atau pengelola perpustakaan masih ada merasa kurang bangga dengan profesinya sehingga berdampak pada kurangnya kualitas dalam memberikan layanan kepada pemustaka. Mereka berpikir posisi pekerjaan tetap aman selagi perpustakaan masih ada.

Namun, sejalan dengan perkembangan teknologi informasi dan komunikasi secara mendasar mempengaruhi teknologi penerbitan yang mengubah hasil penerbitan yang semua berupa penerbitan tercetak menjadi penerbitan elektronik.

Teknologi internet khususnya dalam teknologi web telah membentuk suatu budaya baru yang dikenal dengan "fashion internet", yaitu suatu kondisi dimana internet telah dijadikan sebagai suatu trend atau fashion di dalam penggunaan, pencarian dan penyebaran informasi. ${ }^{1}$.

Sebuah hasil survei pengguna terhadap 1050 mahasiswa di AS menemukan bahwa selama perpustakaan digital, mereka mengunjungi

${ }^{1}$ Ulpah Andayani, 'Manajemen Sumber-Sumber Informasi Elektronik (E-Resources) Di Perpustakaan Akademik', Al Maktabah, 13.1 (2014), 8-19 (p. 8). 
sumber informasi digital yang digunakan adalah: 1) e-jurnal (67\%); 2) katalog perpustakaan (57\%); 3) database dan indeks jurnal (51\%); dan 4) ebooks (21\%). ${ }^{2}$

Berdasarkan laporan survey penetrasi pengguna internet di Indonesia tahun 2018, sebanyak 171, 17 juta jiwa dari total populasi penduduk Indonesia 264,16 atau $64,8 \%$ dari total polulasi Indonesia. Bersadarkan umur yang dominan menggunakan internet antara 10-44 tahun di atas 50-91\% pengguna internet, dengan jenjang pendidikan mulai SMP, namun internet lebih banyak digunakan untuk hiburan (nonton video, game, mendengar musi) (Asosiasi Penyelenggara Jasa Internet Indonesia, 2018), hal ini menandakan masyakakat Indonesia khususnya pada usia remaja sudah sangat familiar menggunakan internet walapun cenderung digunakan untuk sebatas hiburan.

Beberapa literatur memprediksi tantangan yang dihadapai oleh perpustakaan saat sekarang dan bahkan masa depan. Perpustakaan abad ke21 menghadapi tiga tantangan: meningkatnya persaingan untuk pendanaan, meningkatnya harapan pelanggan, dan lingkungan teknologi yang sangat berubah dan kompleks. ${ }^{3}$

Trend ini mulai mengusik keberadaan peran perpustakaan terutama kehadiran sumber-sumber elektronik yang diramalkan secara perlahan koleksi buku tercetak mulai terusik bahkan sangat memungkin tergantikan secara total oleh kehadiran buku elektronik (e-book). Dengan demikinan, perpustakaan pada era ini benar dipilih sebagai pelaku perubahan (agent of change) sebagai tempat penyimpanan informasi sekaligus embrio intelektual diciptakan. ${ }^{4}$

Dalam konteks dunia perpustakaan akademik atau penelitian, seseorang akan kesulitan menemukan orang yang belum pernah mendengar tentang e-book. Namun pengetahuan mendengar belum menjamin

${ }^{2}$ Lucy A. Tedd and Andrew Large, Digital Libraries: Principles and Practice in the Global Environment(München:K·G·Saur München, 2005), p.36<https://doi.org/10.1108/00220410510607525>.

${ }^{3}$ Sara Laughlin and Ray W Wilson, The Quality Library: A Guide to Staff-Driven Improvement, Better Efficiency, and Happier Customers (Chicago: American Library Association, 2008), p. 1.

${ }^{4}$ Wiji. Suwarno, Perpustakaan Dan Buku; Wacana Penulisan Dan Penerbitan (Yogyakarta: Ar-Ruzz Media, 2011), pp. 71-72. 
memahami e-book dalam satu format atau lainnya. Apalagi yang berkaitan dengan cara mengkoleksi untuk dimiliki baik perorangan maupun untuk lembaga pengelola informasi.

Meskipun demikian, mengkoleksi e-book masih terasa sulit untuk diwujudkan pada suatu perpustakaan terutama yang masih menganut paham perpustakaan konvesional artinya perpustakaan cukup berupa buku tercetak saja, belum lagi menyangkut keterbatasan dana dan kemampuan pustakawan. Untuk merealisakan koleksi e-book harus didukung komitmen dan kemampuan yang tinggi pustakawan dan pimpinan lembaga.

\section{Rumusan masalah}

Berdasarkan latar belakang di atas, masalah dapat dirumuskan:

1. Apa saja jenis-jenis e-book di perpustakaan?

2. Apa saja keuntungan dan kekurangan e-book di perpustakaan?

3. Bagaimana strategi meningkatkan kinerja pustakawan dalam mengembangkan koleksi e-book.

\section{Pembahasan}

\section{Pengertian}

Beberapa terminologi yang beragam dalam penggunaan istilah, mulai dari buku eloktronik, buku digital, buku online, bahkan beragam pula menyangkut ejaan dalam penulisan seperti e-book, ebook, e-book, eBook. Namun seringkali dapat digunakan secara bersamaan untuk menjelaskan konsep tersebut, kata itu mengingatkan banyak definisi dan kesan - untuk pustakawan, penerbit, dan konsumen perorangan - hal ini dapat dilihat dari beberapa pengertian, sebagai berikut:

S.S. Rao menunjukkan bahwa kata e-book sering digunakan secara bersamaan untuk menggambarkan konten, format, perangkat lunak pembaca (reader software), dan perangkat membaca (reading devices). (MinčićObradovic, 2011: 15) 
E-book adalah bentuk digital dari sebuah buku memuat informasi tertentu, format penyajian yang runtut, baik bahasanya, tinggi kadar keilmuannya, dan luas pembahasannya. ${ }^{5}$

E-book (elektronic book) atau dikenal dengan istilah buku digital adalah versi elektronik dari buku, berisi informasi digital dapat berupa teks atau gambar. ${ }^{6}$

Buku digital dipahami sebagai publikasi bentuk digital berupa teks dan gambar diproduksi, diterbitkan dan dapat dibaca di komputer atau alat digital lainnya. Dalam Kamus Bahasa Inggris Oxford mengunakan istilah e-book pada buku versi elektronik, singkatan dari Electronic Book atau buku elektronik, adalah sebuah bentuk buku elektronik yang dapat dibuka menggunakan komputer. ${ }^{7}$

Dengan perkembangan teknologi komunikasi dan informasi naskah yang ada disitus web pun dapat dianggap sebagai buku dalam arti luas. Muncul istilah elektronik books, lazim disingkat e-book dalam bahasa Indonesia disebut buku elektronik. Buku elektronik adalah buku pada komputer atau internet dengan gambar, teks dan suara menjadi satu. Buku elektronik mencakup buku yang disimpan di internet, hardisk, CD-ROM, flasdisk, memory, dan CD/DVD. ${ }^{8}$

Buku elektronik. Istilah umum untuk produk penerbitan elektronik dan multimedia, tersedia langsung dari Web atau dalam format fisik pada cakram optik. ${ }^{9}$

Dari pengertian diatas, dapat dipahami bahwa penggunaan perbedaan istilah dan ejaan e-book sering terjadi, tetapi maksudnya sama untuk

${ }^{5}$ Aan Prabowo and Heriyanto, 'Analisis Pemanfaatan Buku Elektronik (e-Book) Oleh Pemustaka Di Perpustakaan SMA Negeri 1 Semarang', Jurnal Ilmu Perpustakaan, 2.2 (2013) <https:// ejournal3.undip.ac.id/index.php/jip/article/view/3123> [accessed 3 November 2018].

${ }^{6}$ Suwarno, p. 74.

${ }^{7}$ Elga Andina, Buku Digital Dan Pengaturannya, Aspirasi: Jurnal Masalah-Masalah Sosial, 2011, II, p. 82 <https://doi.org/https://doi.org/10.22212/aspirasi.v2i1.429>.

${ }^{8}$ Mulyadi, Pengelolaan Perpustakaan Digital (Palembang: Noer Fikri, 2016), p. 5.

9 Ray Prytherch, Harrod's Librarians' Glossary and Reference Book: A Dictionary of over 10,200 Terms, Organizations, Projects and Acronyms in the Areas of Information Management, Library Science, Publishing and Archive Management, Management, 10 th (England: Ashgate, 2005), p. 241. 
menjelaskan suatu buku yang diciptakan dengan cara bentuk digital atau dikonversikan dalam bentuk digital yang ditampilan dilayar komputer atau perangkat lainnya sehingga dapat dibaca.

\section{Munculnya E-Book}

Secara historis kemunculan e-book, diawali dengan munculnya fenomena $e$-publishing sebagai suatu gagasan transformasi penerbitan tercetak menuju penerbitan elektornik sehingga menciptakan pasar buku non-cetak.

Banyak faktor yang memengaruhi perkembangan $e$-book, diantaranya: 1) munculnya desktop publishing; 2) semakin pentingnya penerbitan tanpa kertas; 3) kemudahan informasi elektronik dapat dibuat, diperbarui, disalin, dibagikan, didistribusikan, dan dicari; 4) ketersediaan jaringan komunikasi berbasis komputer lokal dan global; dan 5) awal ledakan informasi elektronik. ${ }^{10}$

Kongres mendirikan Talking Book Programme pada tahun 1931 dan, dengan American Foundation for the Blind, mengembangkan buku-buku pertama yang berbicara (Layanan Perpustakaan Nasional untuk Tunanetra dan Cacat Fisik, 2010). Dengan transisi dari album rekaman ke kaset pada 1960-an dan 1970-an, pasar buku audio tumbuh dan perpustakaan menjadi sumber buku-buku yang tidak dicetak. Akses buku audio diperluas ketika konten dialihkan ke CD dan sekali lagi dengan munculnya iPod dan pemutar MP3 lainnya dari tahun 1990 hingga awal tahun 2000. ${ }^{11}$

Perjalanan e-Book dari awal muncul sampai sekarang dapat dilihat dari gambar di bawah ini:

${ }^{10}$ Ksenija Minčić-Obradovic, E-Books in Academic Libraries (Oxford: Candhos, 2011), p. 12 $<$ https://doi.org/10.1533/9781780630502>.

${ }^{11}$ Building and Managing E-Book Collections: A How-to-Do-It Manual for Librarians, ed. by Richard Kaplan (Chicago: Neal-Schuman, 2012), p. 6 <https://doi.org/10.1108/PROG-08-2013-0043>. 


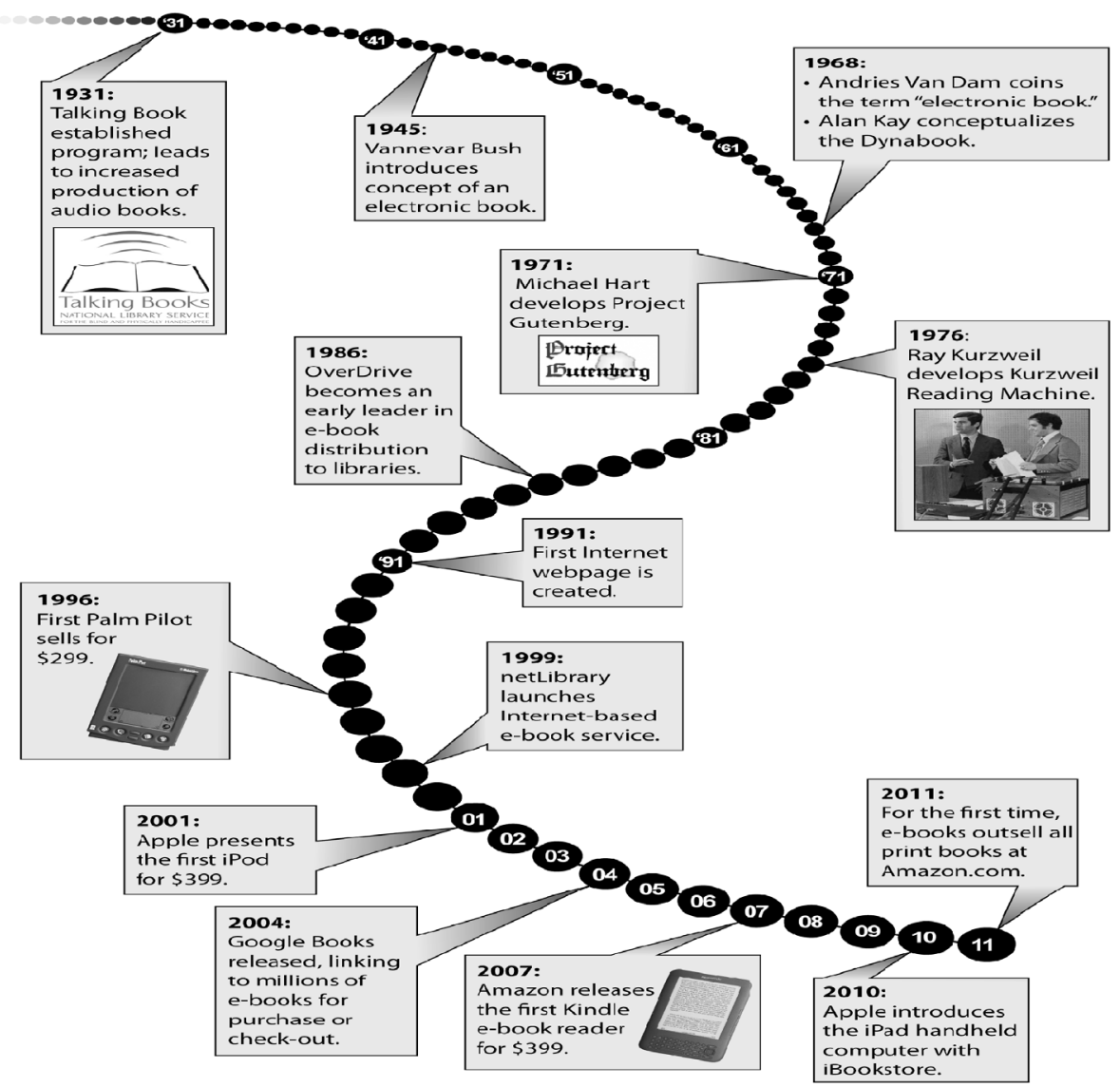

\section{Gambar 1: E-book Timeline (Sumber: Building and Managing E-Book Collections: A How-to-Do-It Manual for Librarians, ed. by Richard Kaplan, Chicago: Neal-Schuman, 2012, p. 7)}

Perkembangan versi elektronik buku dapat dilihat sebagai bagian dari keseluruhan fenomena e-publishing yang dimulai pada tahun 1970-an. Tantangan utama adalah mekanisme pengiriman karena beberapa pengguna ingin 'membaca' buku melalui layar. Tantangan lain terkait dengan masalah hak cipta. ${ }^{12}$

\footnotetext{
${ }^{12}$ Tedd and Large, p. 54.
} 
Di Indonesia, perkembangan $e$-book sudah merambah dunia pendidikan dan lembaga penelitian tanpa terkecuali termasuk perpustakaan, sudah memberikan akses yang luas terhadap koleksi dalam format digital.

Penggunaan buku digital dalam dunia pendidikan difasilitasi dengan program Buku Sekolah Elektronik atau yang disingkat dengan nama BSE, yaitu buku berbentuk digital yang telah diuji kelayakan pakainya oleh Badan Standar Nasional Pendidikan (BSNP) dan telah ditetapkan sebagai buku teks pelajaran berdasarkan Peraturan Menteri Pendidikan Nasional (Permendiknas) No. 46 Tahun 2007, Permendiknas No. 12 Tahun 2008, Permendiknas Nomor 34 Tahun 2008, dan Permendiknas No. 41 Tahun 2008. Buku ini meliputi buku mata pelajaran Matematika, Bahasa Indonesia, Bahasa inggris, Ilmu Pengetahuan Alam (IPA), Ilmu Pengetahuan Sosial (IPS), Pendidikan KewargaNegaraan (PKN), Seni Budaya dan Keterampilan (SBK), Pendidikan Jasmani (PENJAS), dan Pendidikan Agama Islam (PAI). ${ }^{13}$

Selain itu, Lembaga Ilmu Pengetahuan Indonesia (LIPI) memfasilitasi bagi penulis dan masyarakat mengakses aneka buku elektronik dengan lisensi terbuka. ${ }^{14}$

\section{Jenis-Jenis E-Book}

Untuk memahami perbedaan jenis-jenis e-book dapat dilihat beberapa sisi, yaitu sifat akses, bentuk, dan cara produksi.

Jenis e-book berdasarkan sifat aksesnya terdiri atas dua jenis, yaitu sifat tertutup dan sifat terbuka. Pertama, yang bersifat tertutup hanya dapat dibaca menggunakan alat dan program khusus (e-book reader). Jenis kedua, sifat terbuka, yaitu dapat dibaca oleh berbagai peralatan digital. E-book jenis ini tersedia di internet dapat dibaca dengan berbagai jenis peralatan digital, mulai dari PC desktop, laptop. ${ }^{15}$

Sedangkan, Buku ditinjau dari bentuk digital dibedakan atas dua bentuk, yaitu buku elektronik dan buku audio. ${ }^{16}$

\footnotetext{
${ }^{13}$ Andina, II, p. 82.

${ }^{14}$ Suwarno, pp. 76-77.

${ }^{15}$ Prabowo and Heriyanto.

${ }^{16}$ Andina, II, p. 82.
} 
Buku elektronik (e-book), buku yang dirancang untuk dibaca berupa file memiliki berbagai format seperti portable document format (pdf) untuk membuka dan membaca menggunakan program acrobat reader atau sejenisnya. Bentuk format hypertext markup (htm), untuk membuka dan membaca menggunakan program browsing atau internet eksplorer secara offline. E-book dapat berupa format aplikasi. E-book dirancang untuk dibaca di perangkat bernama e-Readers atau e-book devices seperti komputer, handphone, iPod dan iPad.

E-book, terdapat berbagai format yang populer, antara lain adalah teks polos, pdf, jpeg, lit, dan html. ${ }^{17}$

Teks polos merupakan format paling sederhana yang tampilannya dapat dilihat dalam setiap peranti lunak menggunakan komputer sederhana. Namun, beberapa device format dapat dibaca menggunakan peranti lunak dengan melakukan penginstalan terlebih dahulu.

Format pdf memiliki kelebihan dalam hal format yang siap untuk dicetak. Bentuknya mirip dengan bentuk buku sebenarnya, dilengkapi fitur pencarian, daftar isi, memuat gambar, pranala luar, dan multimedia. E-book jenis ini cenderung aman dari kerusakan teks aslinya sebab format tidak dapat diubah secara langsung sehingga terjaga keaslianya.

Format JPEG biasanya format untuk jenis buku yang lebih didominasi gambar dibanding teks.

Format LIT merupakan format dari microsoft reader yang memungkinkan teks dalam e-book disesuaikan dengan lebar layar mobile device yang digunakan untuk membacanya. Format ini memiliki kelebihan bentuk huruf yang nyaman untuk dibaca.

Dalam format HTML, gambar dan teks dapat diakomodasi. Layout teks dan gambar dapar diatur, tetapi hasil dari layar kadang tidak sesuai apabila dicetak.

Selain buku digital yang dibaca, ada juga yang dapat didengarkan. Jenis buku digital ini disebut audiobook. Buku audio adalah tren baru

\footnotetext{
${ }^{17}$ Suwarno, pp. 75-76.
} 
dalam dunia perbukuan. Tren ini diperkenalkan oleh Apple melalui iTunesU yang memberikan layanan unduh buku yang dapat didengar. iTunesU saat ini menyediakan lebih dari 35000 kuliah, video, film gratis dari berbagai universitas di dunia. ${ }^{18}$

E-book, dari cara produksi dibedakan atas tiga cara yaitu: 1) reproduksi digital dari sumber daya cetak; 2) muncul sumber daya digital; dan 3) bersamaan dikeluarkan dalam edisi cetak dan online. ${ }^{19}$

Reproduksi digital, proses pembuatan kembali dari suatu buku yang semula berbentuk tercetak selajutnya diadakakan proses perubahan menjadi bentuk digital.

Sumber daya digital, proses buku yang diciptakan murni dari awal sudah berbentuk digital bahkan tidak memiliki bentuk tercetak.

Edisi cetak dan online, proses pembuatan buku dari awal secara bersamaan dibuat buku dalam bentuk tercetak dan dibuat buku dalam bentuk digital.

\section{Keunggulan Dan Kelemahan E-Book}

Pengguna sebagai subjek pencari informasi kecenderungan mempuyai harapan yang tinggi terhadap ketersediaan informasi secara cepat, menarik dan akurat. E-book muncul sebagai upapa memenuhi keinginan pengguna terhadap ketersediaan informasi tersebut. Kehadiran e-book mempunyai sisi keungulan di samping juga mempunyai sisi kelemahan.

Pustakawan dan konsumen mengeksplorasi pilihan mereka dan mempertimbangkan pro dan kontra dari format $e$-book . secara keseluruhan, kelebihan ebook, yaitu: 1) keterlelusuran cepat; 2) modifikasi lebih sering; 3) portabilitas; 4) variasi; 5) keterbacaan; 6) fitur nilai tambah; 7) penghematan ruang. ${ }^{20}$

Keterlelusuran - Pembaca dapat mencari dan menemukan kata atau subjek yang tepat dalam hitungan detik sehingga lebih efisien bahkan

\footnotetext{
${ }^{18}$ Andina, II, p. 82.

${ }^{19}$ Minčić-Obradovic, p. 16.

${ }^{20}$ Kaplan, p. 5.
} 
dapat menemukan sumber lain yang lebih relevan dalam waktu bersamaan. Menurut Prabowo \& Heriyanto ${ }^{21}$, kelebihan e-book adalah kemudahan penelusuran dan membacanya, penghematan bahan kertas, dan kemudahan pengalihan teks.

Modifikasi - E-book dapat diperbarui lebih sering sesuai dengan kebutuhan baik dari segi format bahkan dari segi isinya dapat dibuat format lebih menarik

Portabilitas - Satu perangkat dapat membawa ribuan buku elektronik, bahkan data cukup dalam satu perangkat saja, lebih praktis bahkan dapat dibaca tanpa terbatas waktu dan tempat.

Variasi - Ada banyak perangkat e-reading dan perangkat genggam yang dapat dipilih, seiring perkembangan teknologi yang menyangkut perangkat keras (hardware) dan perangkat lunak (software).

Keterbacaan - Pembaca dapat menambah atau mengurangi ukuran font teks dan ukuran gambar serta angka untuk kemudahan membaca, terutama bagi pengguna yang mengalami kendala dalam penglihatan.

Fitur nilai tambah - Banyak e-book dilengkapi dengan video, audio, kuis, dan efek animasi yang membuatnya lebih interaktif. Penguna dimanjakan dengan format yang menarik sehingga banyak pilihan sesuai dengan keinginan.

Penghematan ruang - E-book mengurangi persyaratan ruang rak untuk perpustakaan, ruang penyimpanan diperpustakaan bisa jadi hanya terkumpul pada satu perangkat saja atau bahkan tidak mempunyai perangkat penyimpanan mandiri cukup mengunakan server secara online yang disediakan oleh jasa sewa perangkat online.

Di samping keunggulan e-book, juga terdapat aspek kerugiannya, antara lain: 1) membaca di layar; 2) daya baterai; 3) masalah keamanan; 4) permanen; 5) kurangnya standarisasi; 6) meminjam buku; 7) biaya tersembunyi; dan 8 ) biaya langsung. ${ }^{22}$

\footnotetext{
${ }^{21}[5]$

${ }^{22}$ Kaplan, pp. 5-6.
} 
Membaca di layar - Tidak selalu lebih baik membaca teks dalam jumlah besar secara online; efek jangka panjang pada mata masih harus dievaluasi, terutama mata mudah lelah sehingga mengurangi fokus dan konsentrasi saat membaca.

Daya baterai - Ini dapat membatasi jumlah waktu Anda membaca atau bekerja dengan $e$-book sekaligus. Perangkat elekronik sangat tergantung dengan daya elektrik. ketahanan daya baterai sangat terbatas, bahkan perangkat baterai cepat rusak saat digunakan secara terus menerus, juga akibat daya elektrik tidak stabil.

Masalah keamanan - Format digital dapat dipengaruhi oleh virus dan malware. Isi $e$-book tidak dapat dibaca karena virus melakuan pemblokiran sistem data pada perangkat, lebih berat lagi data dapat terhapus dari sistem penyimpanan, jaringan koneksi terputus. Permasalahan keamanan lainya, aspek keamanan hak cipta suatu karya.

Permanen - Perangkat dan format konten yang terus berubah membawa akses e-book jangka panjang dipertanyakan. Seringnya perubahan dari isi, sulit untuk mengotrol keaslian dan keakuratan informasinya. Sisi lain, berkaitan dengan pembaharuan perangkat sering terjadinya format konten tidak bisa terbaca. Menurut Minčić-Obradovic ${ }^{23}$ kekurangan e-book s di antaranya, perangkat membaca. E-book tidak dapat dibaca tanpa perangkat dan perangkat lunak elektronik - PC, laptop, dan lainnya.

Meminjam buku - Meskipun saat ini membaik, masih tidak mudah untuk berbagi e-book, terutama penyedia e-book berbayar sangat ketat mengontrol untuk peminjam buku, baik dari jumlah peminjam maupun jumlah yang dipinjam.

Biaya tersembunyi - Dalam pengaturan akademik, penggunaan e-book berbasis web, seperti e-textbooks, dapat menyebabkan peningkatan pencetakan.

Biaya langsung - pembaca E-book bisa mahal bagi pengguna. Untuk perpustakaan, membeli e-book lebih mahal daripada membeli buku cetak.

\footnotetext{
${ }^{23}$, pp. 19-21.
} 
Penerbit $e$-book

Beberapa keunggulan spesifik e-book adalah 1) dapat memasukkan animasi, gambar, suara dan grafik; 2) mungkin lebih murah daripada barang cetakannya.; 3) dapat dikirim secara instan; 4) dapat dicari secara cepat; 5) tidak memburuk seiring waktu. ${ }^{24}$

Pendapat lain, kelebihan perpustakaan digital dibandingkan dengan perpustakaan konvensional antara lain:

Menghemat ruangan. Karena lokasi perpustakaan digital adalah dokumen-dokumen berbentuk digital, maka penyimpanannya akan sangat efisien.

Akses ganda (Multiple access). Kekurangan perpustakaan konvensional adalah akses terhadap kolek-sinya bersifat tunggal. Artinya apabila ada sebuah buku dipinjam oleh seorang anggota perpustakaan, maka anggota yang lain yang akan meminjam harus menunggu buku tersebut ${ }^{25}$

\section{Mengubah Format Koleksi Perpustakaan, Mengubah Kebutuhan Pustakawan}

Petumbuhan $e$-book dari hari ke hari dengan berbagai cara produksi e-book - reproduksi digital, digital murni, cetak teringrasi online - terus mengalami peningkatan, baik yang dilakukan oleh lembaga penerbitan secara khusus maupun lembaga informasi termasuk di dalamnya perpustakaan.

Perpustakaan masa yang lalu bahkah sampai saat ini, masih mengadalkan koleksi buku tercetak, perpustakaan seakan-akan merasa nyaman dengan koleksi buku tercetak dengan pekerjaan teknis yang dilakukan secara rutin. Sedangkan harapan pengguna perpustakaan mulai berangsur-angsur beralih ke $e$-book untuk mencari informasi.

Tren tersebut merupakan salah satu tantangan sangat besar terhadap keberadaan perpustakaan dan pustakawan abad ini. Bhat, K. Shivananda dkk merilis tantangan utama perpustakaan dan pustakwan abad 21 sebagai berikut:

\footnotetext{
${ }^{24}$ Tedd and Large, pp. 56-57.

${ }^{25}$ Mulyadi, p. 38.
} 
“1) ledakan informasi; 2) revolusi teknologi informasi dan komunikasi; 3 ) pertumbuhan peledak dan penggunaan sumber daya web; 4) berkurangnya anggaran perpustakaan; 5) meningkatnya biaya dokumen cetak; 6) penggunaan intensif sumber daya digital; 7) tingkat harapan pengguna semakin tinggi; 8) lingkungan belajar virtual interaktif ; 9) evolusi lembaga pendidikan maya; 10; berubahnya sifat dan jumlah sumber daya informasi; 11) pola-pola baru dari penerbitan ilmiah dan komunikasi; 12) pengembangan perpustakaan digital, virtual dan hybrid; 13) toko buku online dan layanan informasi. tantangan-tantangan ini telah menyerukan reorientasi, rekayasa ulang, transformasi dan perubahan besar dalam lingkungan informasi, fungsi perpustakaan dan peran perpustakaan dan layanan informasi profesional". ${ }^{26}$

Perpustakaan digital memiliki dua orientasi utama. Di satu sisi, sangat teknis - benar-benar bergantung pada teknologi digital saat itu. Di sisi lain, bersifat sosial, bahkan bersifat pribadi. ${ }^{27}$

Dengan peningkatan besar sumber daya dalam format elektronik, segera menemukan bahwa perubahan dalam kegiatan yang diperlukan untuk mendukung dan memaksimalkan kegunaan menghasilkan perubahan dalam tugas yang dilakukan oleh staf. Pada saat yang sama dengan volume bahan elektronik meningkat, jumlah bahan cetak berkurang secara signifikan setiap tahun, membutuhkan lebih sedikit tugas yang terkait dengan pemeliharaan cetak. Dengan bergesernya tugas, keterampilan yang digunakan staf dalam lingkungan yang lebih kaya cetak belum tentu sama dengan keterampilan yang sekarang dibutuhkan. ${ }^{28}$

Lebih lanjut, Mackellar memandang tugas penting pustakawan pada abad 21 ini:

1. Memilih bahan dan sumber daya elektronik

2. Mengakuisisi bahan dan sumber daya yang dipilih

${ }^{26}$ Jamridafrizal Jamridafrizal, 'Siapkah Pustakawan Menghadapi Eradigital ?', Al-Maktabah, 16.1 (2018), 41-50 (p. 43).

${ }^{27}$ Evaluation of Digital Libraries: An Insight into Useful Applications and Methods, ed. by Giannis Tsakonas and Christos Papatheodorou, Chandos (Oxford: Chandos Publishing, 2009), p. 1 $<$ https://doi.org/10.1007/s00799-007-0011-z>.

${ }^{28}$ Kaplan, p. 159. 
3. Mengorganisir dan memberikan akses kepada mereka

4. Memelihara dan melestarikannya

5. Membantu pengguna perpustakaan

6. Menginstruksikan pengguna perpustakaan

7. Mengelola dan mengelola perpustakaan, personel perpustakaan, layanan, dan program. ${ }^{29}$

Menurut Wibowo (2016: 367) mengutip spencer dan spencer, strategi dapat diterapkan sebagai untuk meningkatkan kinerja pegawai antara lain: 1) job redesign; 2) delegation; 3) skill training; dan 4) career development.

Job redesign (mendesain ulang pekerjaan) - merancang ulang pekerjaan sesuai perkembangan zaman, pustakawan yang selama ini bergelut dengan rutinitas mengelola koleksi buku tercetak, sudah seharusnya mudah merencanakan bahkan melakukan pengembangan koleksi $e$-book dengan cara reproduksi digital koleksi yang telah ada atau melanggan $e$-book secara online.

Delegation (delegasi) - perubahan koleksi buku tercetak menuju koleksi e-obook online memerlukan keahlian khusus. Pustakawan mempunyai keahlian yang beragam, maka memberikan tugas kepada orang sesuai keahlian sehingga dapat melakukan pekerjaan secara tepat dan cepat.

Skill training (pelatihan keterampilan) - perkembangan teknologi begitu pesat berdampak pada keberadaan pustakawan, pengetahuan yang dimiliki pustakawan saat ini kemungkinan kurang relevan dengan bidang pekerjaan yang sedang dilakukan. Untuk mengatasi kekurangan tersebut, pustakawan dituntut selalu mengasah keahliannya dengan mengikuti berbagai pelatihan dan pendidikan berkelanjutan sesuai bidang.

Career development (pengembangan karier) - untuk menjaga motivasi kerja pustakawan, terutama pustakawan yang berprestasi diberikan kesempatan meningkatkan karir yang lebih baik.

${ }^{29}$ Pamela H. MacKellar, The Accidental Librarian (New Jersey: Information Today, 2008), p. 3. 


\section{Penutup}

Sebagai penutup disimpulkan bahwa istilah e-book digunakan untuk menjelaskan suatu buku yang diciptakan dengan cara bentuk digital atau dikonversikan dalam bentuk digital yang ditampilan dilayar komputer atau perangkat lainnya sehingga dapat dibaca. Perbedaan jenis-jenis e-book dapat dibedakan terdiri atas sifat akses, bentuk, dan cara produksi.

Keuntungan e-book adalah 1) keterlelusuran cepat; 2) modifikasi lebih sering; 3) portabilitas; 4) variasi; 5) keterbacaan; 6) fitur nilai tambah; 7) penghematan ruang. Sisi kelemahan e-book adalah 1) membaca di layar; 2) daya baterai; 3) masalah keamanan; 4) permanen; 5) kurangnya standarisasi; 6) meminjam buku; 7) biaya tersembunyi; dan 8) biaya langsung.

Perpustakaan merupakan suatu lembaga yang selalu berkembang, strategi utama peningkatan kinerja pustakawan melalui upaya job redesign, delegation, skill training, dan career development. Pustakawan sebagai agen perubahan untuk mengembangkan perpustakaan ke arah yang lebih baik.

\section{Daftar Pustaka}

Andayani, Ulpah, 'Manajemen Sumber-Sumber Informasi Elektronik (E-Resources) Di Perpustakaan Akademik', Al Maktabah, 13 (2014), 8-19

Andina, Elga, Buku Digital Dan Pengaturannya, Aspirasi: Jurnal MasalahMasalah Sosial, 2011, II <https://doi.org/https://doi.org/10.22212/ aspirasi.v2i1.429>

Jamridafrizal, Jamridafrizal, 'Siapkah Pustakawan Menghadapi Eradigital ?, Al-Maktabah, 16 (2018), 41-50

Kaplan, Richard, ed., Building and Managing E-Book Collections: A How-toDo-It Manual for Librarians (Chicago: Neal-Schuman, 2012) <https:// doi.org/10.1108/PROG-08-2013-0043>

Laughlin, Sara, and Ray W Wilson, The Quality Library: A Guide to StaffDriven Improvement, Better Efficiency, and Happier Customers (Chicago: American Library Association, 2008) 
MacKellar, Pamela H., The Accidental Librarian (New Jersey: Information Today, 2008)

Minčić-Obradovic, Ksenija, E-Books in Academic Libraries (Oxford: Candhos, 2011) <https://doi.org/10.1533/9781780630502>

Mulyadi, Pengelolaan Perpustakaan Digital (Palembang: Noer Fikri, 2016)

Prabowo, Aan, and Heriyanto, 'Analisis Pemanfaatan Buku Elektronik (e-Book) Oleh Pemustaka Di Perpustakaan SMA Negeri 1 Semarang, Jurnal Ilmu Perpustakaan, 2 (2013) <https://ejournal3.undip.ac.id/ index.php/jip/article/view/3123> [accessed 3 November 2018]

Prytherch, Ray, Harrod's Librarians' Glossary and Reference Book: A Dictionary of over 10,200 Terms, Organizations, Projects and Acronyms in the Areas of Information Management, Library Science, Publishing and Archive Management, Management, 10 th (England: Ashgate, 2005)

Suwarno, Wiji., Perpustakaan Dan Buku; Wacana Penulisan Dan Penerbitan (Yogyakarta: Ar-Ruzz Media, 2011)

Tedd, Lucy A., and Andrew Large, Digital Libraries: Principles and Practice in the Global Environment (München: K. G. Saur München, 2005) <https://doi.org/10.1108/00220410510607525>

Tsakonas, Giannis, and Christos Papatheodorou, eds., Evaluation of Digital Libraries : An Insight into Useful Applications and Methods, Chandos (Oxford: Chandos Publishing, 2009) <https://doi.org/10.1007/s00799007-0011-z> 